\title{
Article
}

\section{Catalytic activity of Ag/SBA-15 for low-temperature gas-phase selective oxidation of benzyl alcohol to benzaldehyde}

\author{
Liang Ma ${ }^{\mathrm{a}}$, lihua Jia ${ }^{\mathrm{b}, *}$, Xiangfeng Guo ${ }^{\mathrm{a}, \#}$, Lijun Xiang ${ }^{\mathrm{b}}$ \\ a Key Laboratory of Fine Chemicals of College of Heilongjiang Province, Qiqihar University, Qiqihar 161006, Heilongjiang, China \\ b College of Chemistry and Chemical Engineering, Qiqihar University, Qiqihar 161006, Heilongjiang, China
}

\section{A R T I C L E I N F O}

\section{Article history:}

Received 11 August 2013

Accepted 22 September 2013

Published 20 January 2014

\section{Keywords:}

Silver

SBA-15

Low-temperature gas-phase oxidation

Benzyl alcohol

Benzaldehyde

\begin{abstract}
A B S T R A C T
Ag/SBA-15 catalysts with different Ag contents were prepared by an impregnation method and were used for the gas-phase selective oxidation of benzyl alcohol to benzaldehyde with $\mathrm{O}_{2}$ as the oxidant. These catalysts were characterized using $\mathrm{N}_{2}$ adsorption-desorption, $\mathrm{X}$-ray diffraction, scanning electron microscopy, high-resolution transmission electron microscopy, inductively coupled plasma mass spectrometry, and X-ray photoelectron spectroscopy. The effects of Ag loading, reaction temperature, and weight hourly space velocity of benzyl alcohol on the catalytic performance were investigated. The results showed that Ag was successfully incorporated into the mesoporous channels of SBA-15 and well dispersed on the surface as a result of the nano-confinement effect of SBA-15, which increased the specific surface area of the active components. Moreover, Ag/SBA-15 had a uniform pore size, a wall of thickness of 3-5 nm, and a high specific surface area of 411-541 $\mathrm{m}^{2} / \mathrm{g}$. The catalytic activity of Ag/SBA-15 for the gas-phase selective oxidation of benzyl alcohol to benzaldehyde was enhanced by oxygen spillover of nucleophilic oxygen species from the Ag nanoparticles to the SBA-15 surface. The 5.3\%Ag/SBA-15 exhibited excellent low-temperature catalytic properties; when the reaction temperature was $220^{\circ} \mathrm{C}$, the conversion of benzyl alcohol and the selectivity for benzaldehyde reached $87 \%$ and $95 \%$, respectively. At $240{ }^{\circ} \mathrm{C}$, the catalyst displayed the best catalytic properties, achieving a benzyl alcohol conversion of $94 \%$ and benzaldehyde selectivity of $97 \%$, which remained almost constant at $240-300^{\circ} \mathrm{C}$. This showed that Ag/SBA-15 had excellent thermal gradient stability. The catalyst could be used for $40 \mathrm{~h}$ and retained high catalytic activity for oxidation after treatment at $500^{\circ} \mathrm{C}$.
\end{abstract}

(C) 2014, Dalian Institute of Chemical Physics, Chinese Academy of Sciences. Published by Elsevier B.V. All rights reserved.

\section{Introduction}

Benzaldehyde is an important intermediate in organic synthesis [1] and is widely used in cosmetics, perfumery, food, and pharmaceutical industries [2]. At present, benzaldehyde is mainly produced by the gas-phase oxidation of toluene [3] or liquid-phase oxidation of benzyl alcohol [4-6] on industrial and laboratory scales. However, these processes lead to generation of large amounts of by-products, which are difficult to separate, and the selectivity is poor; this limits benzaldehyde applications. Recently, gas/solid-phase selective oxidation of benzyl alcohol to benzaldehyde using $\mathrm{O}_{2}$ as the oxidant in the presence

\footnotetext{
* Corresponding author. Tel: +86-452-2742573; E-mail: jlh29@163.com

\# Corresponding author. Tel: +86-452-2742563; E-mail: xfguo@163.com

This work was supported by the National Natural Science Foundation of China (21176125), the Science Research Project of the Ministry of Education of Heilongjiang Province of China (12521594, 2012TD012, JX201205), the Natural Science Foundation of Heilongjiang Province of China (B201114, B201313), and the Key Program of Science and Technology of Qiqihar, Heilongjiang Province (GYGG-201108).

DOI: 10.1016/S1872-2067(12)60720-7 | http://www.sciencedirect.com/science/journal/18722067 | Chin. J. Catal., Vol. 35, No. 1, January 2014
} 
of a heterogeneous catalyst in a packed bed reactor has attracted much attention because the process is solvent free and generates a small amount of by-products, and the products are easily separated. Supported metal catalysts such as $\mathrm{Au}-\mathrm{Cu} / \mathrm{SiO}_{2}$ [7], $\mathrm{Au} / \mathrm{Ni}$ fibers [8], $\mathrm{Ag} / \mathrm{SiO}_{2}$ [9], microfibrous $\mathrm{Ag}[10,11]$, thin-sheet Ag/Ni fibers [12], and Ag-HMS [13] have been widely used in gas-phase selective oxidation of benzyl alcohol to benzaldehyde. Many of these catalysts showed good activities and selectivities, but the reaction temperature in most cases was above $300{ }^{\circ} \mathrm{C}$. Galvanic deposition of Au onto sinter-locked $\mathrm{Ni}$ fibers delivered an excellent $\mathrm{Au} / \mathrm{Ni}$ fiber catalyst [14] for low-temperature gas-phase benzyl alcohol oxidation. An $\mathrm{Au}$ catalyst loading of $4 \%$ and a reaction temperature of $240{ }^{\circ} \mathrm{C}$ were used, and a benzyl alcohol conversion of $99 \%$ and selectivity for benzaldehyde of $98 \%$ were achieved. Recently, a $\mathrm{K}-\mathrm{Cu}-\mathrm{TiO}_{2}$ catalyst [15] was used in gas-phase benzyl alcohol oxidation to benzaldehyde at low temperature, i.e., $203-223^{\circ} \mathrm{C}$, giving a benzyl alcohol conversion of $72 \%$ and selectivity for benzaldehyde of $98 \%$. However, the catalyst was temperature sensitive; a slightly higher reaction temperature (above $250{ }^{\circ} \mathrm{C}$ ) led to total oxidation of benzyl alcohol to undesired benzyl acid. Low-temperature gas-phase selective oxidation of benzyl alcohol to benzaldehyde not only gives improved selectivity for benzaldehyde but also conforms to the guiding principles of green chemistry, so it has been attracting increasing attention [16].

SBA-15 mesoporous materials have highly ordered hexagonally arranged cylindrical pore structures, and the pore diameters can be systematically changed from 4.6 to $30 \mathrm{~nm}$; they have thick walls, high specific surface areas, and good hydrothermal stabilities. Moreover, they have an abundance of surface $\mathrm{Si}-\mathrm{OH}$ groups, and this is favorable for modification of SBA-15. The nano-confining effect of SBA-15 can be used to construct nanometer-scale active species; this is an effective method for producing functional nanomaterials [17-22], so it is widely used industrially for catalysts and adsorbents [23-31]. Ag-modified SBA-15 [32-37] has attracted the interest of many researchers for formaldehyde oxidation [38], selective oxidation of cycloalkanes [39], and CO oxidation [40-42] because of its remarkable catalytic performance. However, the application of Ag/SBA-15 in gas-phase selective oxidation of benzyl alcohol to benzaldehyde has rarely been reported.

In this study, a series of Ag/SBA-15 catalysts with different Ag loadings were synthesized using an impregnation method. The structure and active component of Ag/SBA-15 were characterized using $\mathrm{N}_{2}$ adsorption-desorption, X-ray diffraction (XRD), scanning electron microscopy (SEM), high-resolution transmission electron microscopy (HRTEM), X-ray photoelectron spectroscopy (XPS), and inductively coupled plasma mass spectrometry (ICP-MS). The catalysts were used in the gas-phase selective oxidation of benzyl alcohol to benzaldehyde with molecular oxygen as the oxidant, without any additives. The effect of Ag loading on the catalyst structure and the relationship between the structure and activity of the catalyst were investigated. The influence of reaction temperature on the conversion of benzyl alcohol and benzaldehyde selectivity was probed. The catalyst reusability was also investigated.

\section{Experimental}

\subsection{Catalyst preparation}

SBA-15 was synthesized according to the procedure reported in the literature [43,44]. A typical synthetic procedure was as follows. The triblock copolymer pluronic (P123, $\mathrm{EO}_{20} \mathrm{PO}_{70} \mathrm{EO}_{20}, M_{\mathrm{w}}=5800$, Sigma-Aldrich, $4.2 \mathrm{~g}$ ) was dissolved in $150 \mathrm{~mL}$ solution containing $60 \mathrm{~g}$ of $\mathrm{HCl}(4.0 \mathrm{~mol} / \mathrm{L})$ and $90 \mathrm{~g}$ of deionized water, and the solution was stirred for $2 \mathrm{~h}$ at $40^{\circ} \mathrm{C}$. Tetraethyl orthosilicate ( $8.5 \mathrm{~g}, \mathrm{AR}, 98 \%$ ) was then dropped into the solution and hydrolyzed at $40{ }^{\circ} \mathrm{C}$ for $24 \mathrm{~h}$ under vigorous stirring. The mixture was transferred to a Teflon vessel, and the vessel was sealed and heated at $100{ }^{\circ} \mathrm{C}$ for $24 \mathrm{~h}$ without stirring. The white solid formed was separated by filtration, washed three times with deionized water, dried at $60{ }^{\circ} \mathrm{C}$ overnight and calcined at $550{ }^{\circ} \mathrm{C}$ for $6 \mathrm{~h}$, giving SBA-15 as a white powder.

A simple impregnation method was used to prepare Ag/SBA-15 catalysts based on previous reports [39,45]. Samples of SBA-15 support (1.0 g) were immersed in $50 \mathrm{~mL}$ of aqueous solutions containing different amounts of $\mathrm{AgNO}_{3}$ under stirring. The slurry was stirred for $10 \mathrm{~h}$ at $50{ }^{\circ} \mathrm{C}$. The wet samples obtained were dried at $80^{\circ} \mathrm{C}$ for $12 \mathrm{~h}$ and calcined at $550{ }^{\circ} \mathrm{C}$ in air for $6 \mathrm{~h}$. The samples were denoted by $x \mathrm{Ag} / \mathrm{SBA}-15$, where $x$ represents the Ag loading (mass fraction) determined using ICP-MS. In addition, after use for $40 \mathrm{~h}, 5.3 \% \mathrm{Ag} / \mathrm{SBA}-15$ was washed with ethanol, filtered, dried at $80{ }^{\circ} \mathrm{C}$ for $12 \mathrm{~h}$, and calcined at $500{ }^{\circ} \mathrm{C}$ for $2 \mathrm{~h}$ to giving regeneration catalyst and the sample was denoted by $5.3 \% \mathrm{Ag} / \mathrm{SBA}-15-\mathrm{A}$.

\subsection{Catalyst characterization}

Powder XRD patterns were recorded with a Bruker D8 Advance (Germany) diffractometer using $\mathrm{Cu} K_{\alpha}$ radiation $(\lambda=$ $1.5418 \AA$ ); the scanning speed was $3^{\circ} / \mathrm{min}$ and the scanned area was $2 \theta=0.5^{\circ}-80^{\circ}$. $\mathrm{N}_{2}$ adsorption isotherms were measured at $-196{ }^{\circ} \mathrm{C}$ using a Quantachrome NOVA2000e instrument. The samples were degassed at $300{ }^{\circ} \mathrm{C}$ for $3 \mathrm{~h}$ under vacuum $\left(1 \times 10^{-3}\right.$ Torr $)$ before the measurements. The specific surface area, pore size, and pore volume were determined using the BET and BJH methods. The sample morphologies were observed by SEM using a Rigaku S-4300 spectrometer (Japan); the voltage was $20 \mathrm{kV}$, and the vacuum degree of the sample room was better than $1 \times 10^{-4}$. HRTEM images were obtained using a Tecnai G2 transmission electron microscope (USA) operated at an accelerating voltage of $200 \mathrm{kV}$. The surface chemical compositions of the samples were determined by XPS with an ESCALAB 250Xi spectrometer (Thermo Electron, UK) using a non-monochromatized $\mathrm{Al} K_{\alpha}$ X-ray source $(1486 \mathrm{eV})$. The actual Ag loadings of all the catalysts were determined by ICP-MS using an Agilent 7500ce spectrometer. Before the tests, the catalysts were dissolved in $3 \mathrm{~mL}$ of $\mathrm{HCl}, 1 \mathrm{~mL}$ of $\mathrm{HF}$, and 1 $\mathrm{mL}$ of $\mathrm{HNO}_{3}$, and then the solution volume was increased to $100 \mathrm{~mL}$ using $3 \% \mathrm{HNO}_{3}$.

\subsection{Evaluation of catalytic performance}


The gas-phase oxidation of benzyl alcohol over Ag/SBA-15 was carried out in a conventional continuous-flow fixed-bed reactor (stainless-steel tube, inner diameter $6 \mathrm{~mm}$, length 450 $\mathrm{mm})$ at atmospheric pressure. First, the catalyst ( $0.8 \mathrm{~g})$ was sieved to 40-60 mesh powders and pretreated in a flow of $\mathrm{N}_{2}$ and $\mathrm{O}_{2}\left(\mathrm{O}_{2}: \mathrm{N}_{2}\right.$ volume ratio of $3: 7$ and flow rate $\left.50 \mathrm{~mL} / \mathrm{min}\right)$ at $550{ }^{\circ} \mathrm{C}$ for $2 \mathrm{~h}$ before testing. Second, the reactants, consisting of purified $\mathrm{N}_{2}$ (35 mL/min), purified $\mathrm{O}_{2}$, and benzyl alcohol at a weight hourly space velocity (WHSV) $=4.7-12.5 \mathrm{~h}^{-1}$ vaporized at $220^{\circ} \mathrm{C}$, were fed into the reactor bed using a precious liquid pump; the molar ratio of $\mathrm{O}_{2}$ to benzyl alcohol was 0.6. Vaporization of benzyl alcohol was performed in a preheating zone, placed before the catalyst bed, and the reaction was carried out at $220-380{ }^{\circ} \mathrm{C}$. The products were collected using an ice-salt bath $\left(-5\right.$ to $\left.-10{ }^{\circ} \mathrm{C}\right)$, and the products were periodically sampled and analyzed using a gas chromatograph (Cotrun GC9800(N)) fitted with an OV-17 capillary column (30 m $\times 0.25$ $\mathrm{mm} \times 0.25 \mu \mathrm{m})$ and a flame ionization detector. The column temperature was $140{ }^{\circ} \mathrm{C}$, and the detector and injector temperatures were $200{ }^{\circ} \mathrm{C}$. The yield of benzaldehyde was calculated by multiplying the benzyl alcohol conversion by the selectivity for benzaldehyde.

\section{Results and discussion}

\subsection{Catalytic properties of Ag/SBA-15}

\subsubsection{Effect of Ag loading}

The catalytic performance of Ag/SBA-15 in the gas-phase selective oxidation of benzyl alcohol to benzaldehyde is shown in Table 1. SBA-15 had hardly any catalytic activity in the gas-phase selective oxidation of benzyl alcohol at $240{ }^{\circ} \mathrm{C}$. However, after Ag loading, the conversion of benzyl alcohol increased significantly. It was confirmed that $\mathrm{Ag}$ was the active species. With increasing Ag loading from $4.1 \%$ to $16.5 \%$, the conversion of benzyl alcohol increased from $74.8 \%$ to $96.6 \%$, but the selectivity for benzaldehyde first increased from $85.2 \%$ to $96.9 \%$, and then decreased to $91.5 \%$. Ag over-loading led to further oxidation of benzaldehyde to benzoic acid, thus the selectivity was reduced. A catalyst with $5.3 \% \mathrm{Ag}$ gave the best results: a benzyl alcohol conversion of $93.9 \%$, selectivity for benzaldehyde of $96.9 \%$, and a TOF of $128.6 \mathrm{~h}^{-1}$.

\section{Table 1}

Effect of Ag loading on catalytic performance of Ag/SBA-15 in selective oxidation of benzyl alcohol to benzaldehyde.

\begin{tabular}{lcccc}
\hline Catalyst & $\begin{array}{c}\text { Conversion of } \\
\text { benzyl alcohol } \\
(\%)\end{array}$ & $\begin{array}{c}\text { Selectivity for } \\
\text { benzaldehyde } \\
(\%)\end{array}$ & $\begin{array}{c}\text { Yield of } \\
\text { benzaldehyde } \\
(\%)\end{array}$ & $\begin{array}{c}\text { TOFa } \\
\left(\mathrm{h}^{-1}\right)\end{array}$ \\
\hline SBA-15 & 2.0 & 60.5 & 1.24 & - \\
$4.1 \% \mathrm{Ag} / \mathrm{SBA}-15$ & 74.8 & 85.2 & 63.7 & 116.5 \\
$5.3 \% \mathrm{Ag} / \mathrm{SBA}-15$ & 93.9 & 96.9 & 90.9 & 128.6 \\
$8.1 \% \mathrm{Ag} / \mathrm{SBA}-15$ & 94.2 & 96.0 & 90.4 & 83.7 \\
16.5\%Ag/SBA-15 & 96.6 & 91.5 & 88.4 & 40.2 \\
\hline
\end{tabular}

Reaction conditions: catalyst $0.8 \mathrm{~g}, 240^{\circ} \mathrm{C}, n\left(\mathrm{O}_{2}\right) / n$ (benzyl alcohol $)=$ $0.6, \mathrm{WHSV}=7.8 \mathrm{~h}^{-1}$.

a $\mathrm{TOF}=m$ (benzaldehyde $) /[m($ catalyst $) \times x \times \mathrm{t}]$, where $m$ (benzaldehyde) (g) was calculated from the conversion at $1 \mathrm{~h}$ reaction and by assuming that the Ag are active sites, $m$ (catalyst) is equal to $0.8 \mathrm{~g}, x$ is the content of Ag determined by ICP-MS, and $t(\mathrm{~h})$ is the reaction time.

\subsubsection{Effect of reaction temperature}

Temperature is an important factor in the conversion and selectivity of the gas-phase selective oxidation of benzyl alcohol [12-16]. The effect of reaction temperature on the gas-phase selective oxidation of benzyl alcohol was investigated using $5.3 \% \mathrm{Ag} / \mathrm{SBA}-15$ as the catalyst (Fig. 1). It shows that the benzyl alcohol conversion and selectivity for benzaldehyde were $86 \%$ and $95 \%$, respectively, at $220{ }^{\circ} \mathrm{C}$. This indicates that low-temperature gas-phase selective oxidation of benzyl alcohol to benzaldehyde can be achieved using $\mathrm{Ag} / \mathrm{SBA}-15$ as a catalyst. When the temperature increased to $240{ }^{\circ} \mathrm{C}$, a benzyl alcohol conversion of $94 \%$ and a selectivity for benzaldehyde of $97 \%$ were obtained. The results remained almost unchanged with increasing temperature from 240 to $300{ }^{\circ} \mathrm{C}$. However, as the temperature continued to rise to $340{ }^{\circ} \mathrm{C}$, the selectivity dropped to $90 \%$, and the conversion increased slightly. A selectivity of $85 \%$ and conversion of $100 \%$ were achieved until the temperature reached $380{ }^{\circ} \mathrm{C}$. Liquid chromatography-MS analysis showed that the benzaldehyde was partially oxidized to benzoic acid at high temperature, leading to decreased selectivity. These results show that Ag/SBA-15 can be used as the catalyst in the production of benzaldehyde from benzyl alcohol by gas-phase selective oxidation at low temperatures; a high selectivity can be achieved across a wide temperature range, and the catalyst displays excellent thermal gradient stability for the reaction. The reactivity and the selectivity for benzaldehyde can be controlled by regulating the reaction temperature and using an appropriate catalyst.

\subsubsection{Effect of WHSV}

The influence of WHSVs of benzyl alcohol on the conversion, selectivity, and TOF over 5.3\%Ag/SBA-15 is shown in Fig. 2. As the WHSV increased from 4.7 to $12.5 \mathrm{~h}^{-1}$, the selectivity for benzaldehyde increased to above $95 \%$, and the TOF increased from $77.1 \mathrm{~h}^{-1}$ to a maximum of $134.9 \mathrm{~h}^{-1}$ and then decreased to $127.6 \mathrm{~h}^{-1}$; when the WHSV was $7.8 \mathrm{~h}^{-1}$, the conversion of benzyl alcohol and the selectivity for benzaldehyde achieved maximum values of $94 \%$ and $97 \%$, respectively, and the TOF was $128.6 \mathrm{~h}^{-1}$. The maximum TOF value, $134.9 \mathrm{~h}^{-1}$, was found when

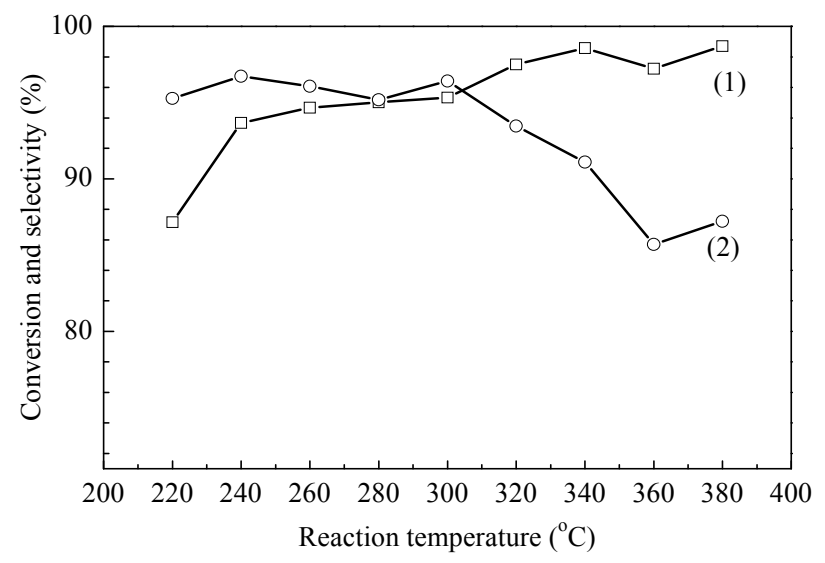

Fig. 1. Conversion of benzyl alcohol (1) and selectivity for benzaldehyde (2) versus reaction temperature over $5.3 \% \mathrm{Ag} / \mathrm{SBA}-15$ for selective oxidation of benzyl alcohol. Reaction conditions: catalyst $0.8 \mathrm{~g}$, $n\left(\mathrm{O}_{2}\right) / n$ (benzyl alcohol $)=0.6, \mathrm{WHSV}=7.8 \mathrm{~h}^{-1}$. 


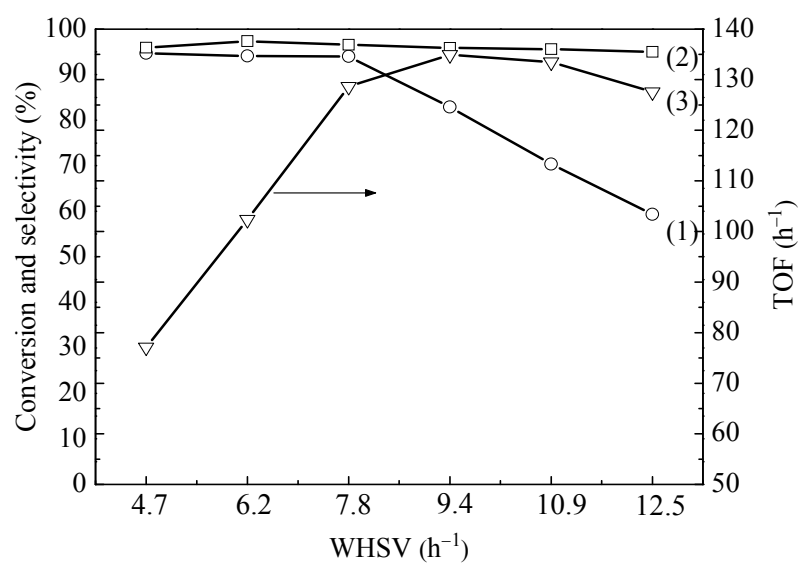

Fig. 2. Influence of different WHSVs $\left(\mathrm{h}^{-1}\right)$ of benzyl alcohol on conversion (1), selectivity (2), and TOF (3) over 5.3\%Ag/SBA-15. Reaction conditions: catalyst $0.8 \mathrm{~g}, 240^{\circ} \mathrm{C}, n\left(\mathrm{O}_{2}\right) / n$ (benzyl alcohol) $=0.6$.

the WHSV was $9.4 \mathrm{~h}^{-1}$, but the benzyl alcohol conversion was only $82.8 \%$. It was concluded that the optimum conditions were reaction temperature $240{ }^{\circ} \mathrm{C}$, amount of catalyst $0.8 \mathrm{~g}$, WHSV $7.8 \mathrm{~h}^{-1}$, and $n\left(\mathrm{O}_{2}\right): n$ (benzyl alcohol) $=0.6$, giving a benzyl alcohol conversion of $94 \%$ and selectivity for benzaldehyde of more than $97 \%$.

\subsection{Relationship between structure and catalytic activity of $\mathrm{Ag} / \mathrm{SBA}-15$}

To investigate the relationship between the structure of Ag/SBA-15 and the catalytic performance, the structure and active ingredients of the catalyst in the gas-phase selective oxidation of benzyl alcohol were determined using $\mathrm{N}_{2}$ adsorption-desorption, XRD, SEM, HRTEM, XPS, and ICP-MS.

The morphology of Ag and its content on the Ag/SBA-15 surface were analyzed using the XPS surface probe technique. The Ag $3 d$ XPS spectra of 5.3\%Ag/SBA-15 are shown in Fig. 3. The Ag $3 d$ binding energy region consisted of asymmetric peaks that could be fitted to two doublets; the energy difference, $\Delta E=6.1 \mathrm{eV}$, was ascribed to the $\mathrm{Ag} 3 d_{3 / 2}(374.4 \mathrm{eV})$ and Ag $3 d_{5 / 2}$ (368.3 eV) core levels of two different species [46,47]: metallic Ag (atomic ratio $90 \%$ of the total Ag $3 d_{5 / 2}$ XPS signal,

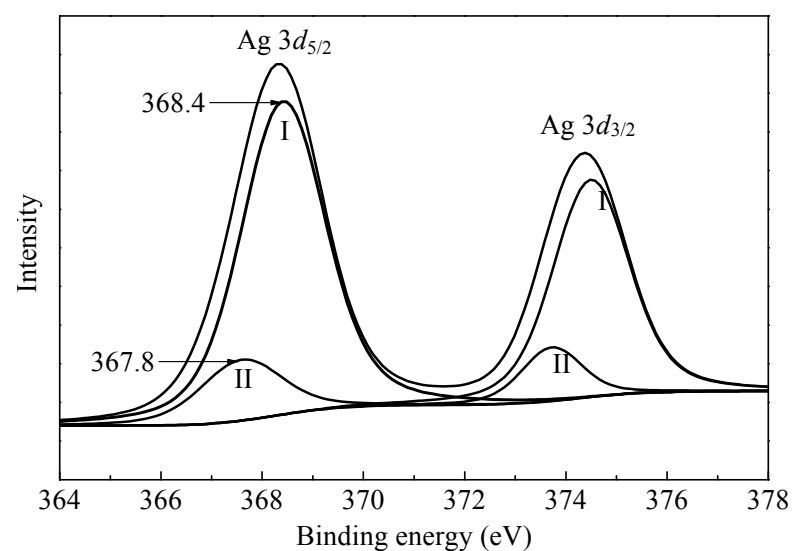

Fig. 3. XPS spectra of $5.3 \% \mathrm{Ag} / \mathrm{SBA}-15$.

$368.4 \mathrm{eV})$ and $\mathrm{Ag}_{2} \mathrm{O}(10 \%, 367.8 \mathrm{eV})$ [48]. These results show that the Ag particles on the $\mathrm{Ag} / \mathrm{SBA}-15$ surface consist of metallic Ag and oxidized Ag species [13] at $0.33 \%$ of the mass fraction of Ag. In addition, ICP-MS analysis showed that the percentage content of $\mathrm{Ag}$ was $5.3 \%$ for the $5.3 \% \mathrm{Ag} / \mathrm{SBA}-15$ sample, so it can be estimated that the mass fraction of $\mathrm{Ag}$ in the SBA-15 mesopores was about $4.93 \%$, i.e., more than $93 \%$ of the Ag was in the channels of mesoporous SBA-15. Combining the catalytic performance tests, it was concluded that Ag is the active species for gas-phase selective oxidation of benzyl alcohol to benzaldehyde.

The $\mathrm{N}_{2}$ adsorption-desorption isotherms of the catalyst and the BJH pore size distribution curves are shown in Fig. 4. The $\mathrm{N}_{2}$ adsorption-desorption isotherms of all the samples are type IV at high relative pressures $\left(0.6<p / p_{0}<0.8\right)$ because capillary condensation under $\mathrm{N}_{2}$ presents an $\mathrm{H} 1$ hysteresis loop, Fig. 4(a). The adsorption and desorption branches across a narrow range of pressures displayed clear parallel trends. This is consistent with the SBA-15 molecular sieves having uniform open cylindrical pores $(d>6 \mathrm{~nm})$ [43-45,49]; however, with increasing Ag loading, the Ag/SBA-15 samples showed a wide range of relatively flat pressure hysteresis loops, and the adsorption and desorption branches closed at slightly lower pressures. According to Kelvin's law, the low pressure of capillary condensation when the aperture size decreased indicated
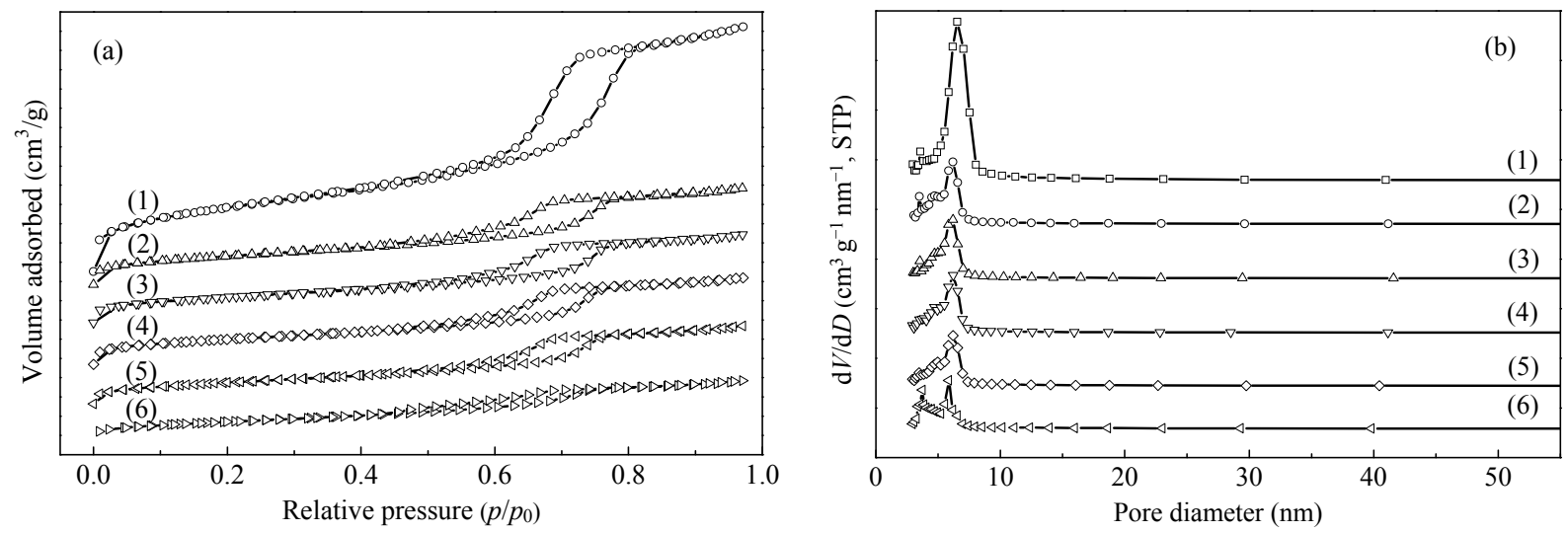

Fig. 4. $\mathrm{N}_{2}$ adsorption-desorption isotherms (a) and pore size distribution curves (b) of Ag/SBA-15. (1) SBA-15; (2) 4.2\%Ag/SBA-15; (3) 5.3\%Ag/ SBA-15; (4) 8.1\%Ag/SBA-15; (5) 16.5\%Ag/SBA-15; (6) 5.3\%Ag/SBA-15-A. 
Table 2

Physicochemical properties of Ag/SBA-15.

\begin{tabular}{lcccc}
\hline Catalyst & $\begin{array}{c}A_{\mathrm{BET}^{\mathrm{a}}} \\
\left(\mathrm{m}_{2} / \mathrm{g}\right)\end{array}$ & $\begin{array}{c}D^{\mathrm{b}} \\
(\mathrm{nm})\end{array}$ & $\begin{array}{c}V^{\mathrm{c}} \\
\left(\mathrm{cm}^{3} / \mathrm{g}\right)\end{array}$ & $\begin{array}{c}D_{\mathrm{Ag}}{ }^{\mathrm{d}} \\
(\mathrm{nm})\end{array}$ \\
\hline SBA-15 & 676 & 6.57 & 0.87 & - \\
$4.2 \% \mathrm{Ag} / \mathrm{SBA}-15$ & 541 & 6.28 & 0.73 & 5.5 \\
$5.3 \% \mathrm{Ag} / \mathrm{SBA}-15$ & 546 & 6.19 & 0.67 & 6.4 \\
$8.1 \% \mathrm{Ag} / \mathrm{SBA}-15$ & 476 & 6.20 & 0.66 & 10.2 \\
$16.5 \% A g / \mathrm{SBA}-15$ & 411 & 6.18 & 0.60 & 17.4 \\
$5.3 \% \mathrm{Ag} / \mathrm{SBA}-15-\mathrm{A}$ & 452 & 5.57 & 0.55 & 15.5 \\
\hline
\end{tabular}

a Surface area derived from BET equation.

b Pore diameter derived by BJH method using desorption branch.

c Pore volume obtained from the volume of $\mathrm{N}_{2}$ adsorbed at a relative pressure of 0.99 .

d Ag particle size calculated using HRTEM images.

that the sample has ink-bottle-type channels [13,50]. Channel formation may be caused by Ag entering the pores. It can be seen from Fig. 4(b) that the average pore size became smaller and the pore size distribution broadened. The pore size distributions of $4.2 \% \mathrm{Ag} / \mathrm{SBA}-15$ and $5.3 \% \mathrm{Ag} / \mathrm{SBA}-15$ appeared at $d$ $=3.7 \mathrm{~nm}$. This is an illusion that originates from the narrow orifice of the ink-bottle-shaped channel, and further demonstrates the presence of $\mathrm{Ag}$ in the SBA-15 channels. The structural parameters of Ag/SBA-15 are shown in Table 2. As the Ag loading increased from 0 to $16.5 \%$, the specific surface area, pore volume, and pore size of the catalyst decreased from 676 $\mathrm{m}^{2} / \mathrm{g}, 0.886 \mathrm{~cm}^{3} / \mathrm{g}$, and $6.57 \mathrm{~nm}$, respectively, to $411 \mathrm{~m}^{2} / \mathrm{g}$, $0.607 \mathrm{~cm}^{3} / \mathrm{g}$, and $6.19 \mathrm{~nm}$, respectively. This may be caused by the Ag particles in the channels occupying part of the pore space in the channels, so the specific surface area, pore volume, and pore size decrease. A pore size of $d=6-7 \mathrm{~nm}$ was calculated from the desorption branch, which indicated that channels with $d=3.7 \mathrm{~nm}$ were not present in the samples. The $\mathrm{N}_{2}$ adsorption-desorption isotherms and $\mathrm{BJH}$ pore size distribution curves further proved that the Ag loading did not affect the ordered porous structure of SBA-15, and the active Ag species entered the SBA-15 channels.

Figure 5(a) shows the small-angle XRD patterns of the Ag/SBA-15 catalysts. All the samples showed two diffraction peaks in the range $2 \theta=1.4^{\circ}-2^{\circ}$. This shows that $\mathrm{Ag} / \mathrm{SBA}-15$ retains the typical hexagonal mesoporous structure [43]. When

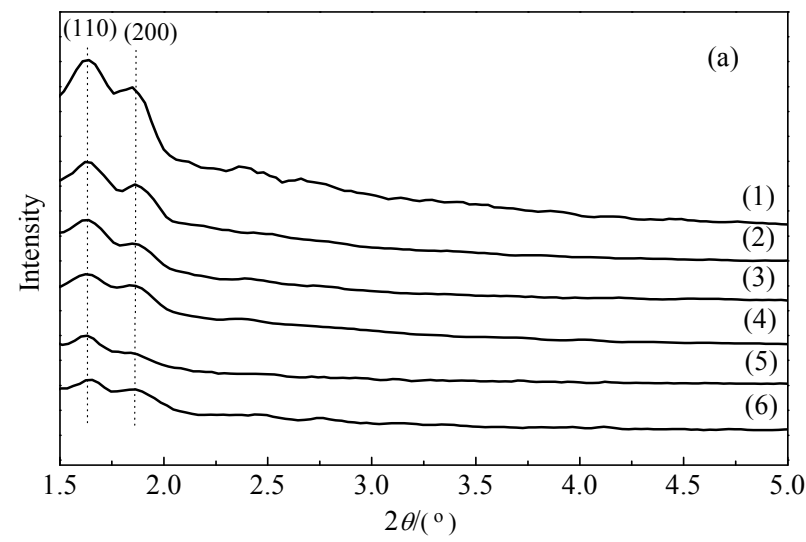

the Ag loading was $16.5 \%$, the intensities of the diffraction peaks declined significantly. An Ag loading that is too high results in aggregation of Ag in the SBA-15 channels, so the channel structure changes. Figure 5(b) shows the wide-angle XRD patterns of the samples. When the Ag loadings were $4.2 \%$ and $5.3 \%$, the Ag diffraction peaks were not obvious. This shows that Ag nanoparticles were highly dispersed on the carrier surface. When the Ag loading was increased to $16.5 \%$, the intensities of four diffraction peaks at $2 \theta=38.4^{\circ}, 44.0^{\circ}, 64.3^{\circ}$, and $77.5^{\circ}$, corresponding to the four crystal planes, i.e., (111), (200), (220), and (311), of cubic Ag (JCPDS No. 4-07830) $[13,34,48]$ increased and narrowed. This illustrated that the form of Ag changed from a highly dispersed state to an aggregated state. These results are consistent with the XPS and $\mathrm{N}_{2}$ adsorption-desorption results.

Figure 6 shows SEM and HRTEM images of the SBA-15 and Ag/SBA-15 catalysts. It shows that the SBA-15 support (Fig. 6(a)) was a long rope connected with short rods, with clear corrugations and minor grooves on the surface. There are no significant differences among the appearances of $5.3 \% \mathrm{Ag} /$ SBA-15 (Fig. 6(b)) and pure SBA-15, and they are identical to those reported in the literature $[43,44]$. This shows that the Ag loading using the impregnation method did not affect the appearance of SBA-15. Figure 6(d) shows that the SBA-15 channels were ordered and the cross-section was hexagonal (the figure shows a TEM image of SBA-15 perpendicular to the C6 axis). This is a typical two-dimensional hexagonal mesoporous structure [51]. The aperture is about $6-8 \mathrm{~nm}$, and the wall thickness is about $3-5 \mathrm{~nm}$. Figure $6(\mathrm{e}-\mathrm{h})$ show that the Ag/SBA-15 still has a long-range ordered and uniform pore structure after Ag loading. This is in agreement with the reported results $[49,50]$. When the Ag loadings were $4.2 \%$ and $5.3 \%$, the $\mathrm{Ag}(\sim 6 \mathrm{~nm})$ was highly dispersed on the SBA-15 carrier. As the Ag loading increased to $16.5 \%$, some of the Ag particles gathered in the SBA-15 channels and formed nanorods of length $10-30 \mathrm{~nm}$, and occupied part of the channels. This is in agreement with the XPS, $\mathrm{N}_{2}$ adsorption-desorption, and XRD results.

Structural analysis of the catalysts and catalytic performance experiments showed that $\mathrm{Ag}$ is the active species in $\mathrm{Ag} / \mathrm{SBA}-15$, and the Ag loading, particle size, and dispersion

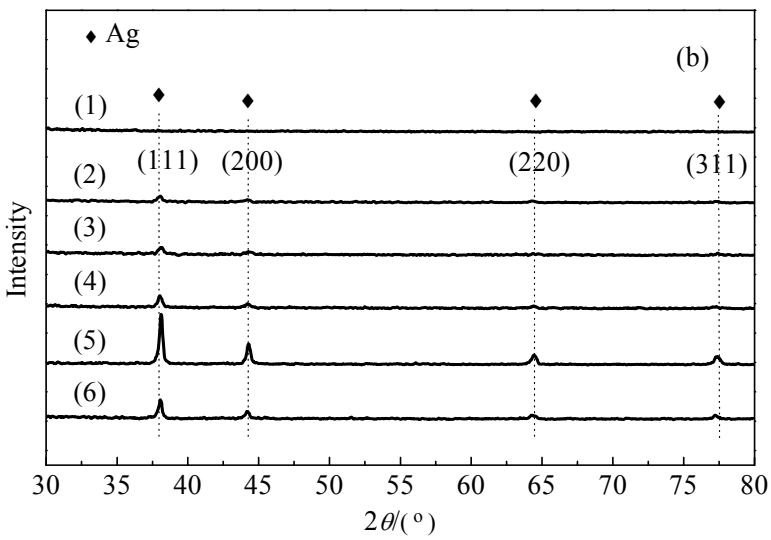

Fig. 5. XRD patterns of Ag/SBA-15 in small-angle range (a) and wide-angle range (b). (1) SBA-15; (2) 4.2\%Ag/SBA-15; (3) 5.3\%Ag/SBA-15; (4) 8.1\%Ag/SBA-15; (5) 16.5\%Ag/SBA-15; (6) 5.3\%Ag/SBA-15-A. 


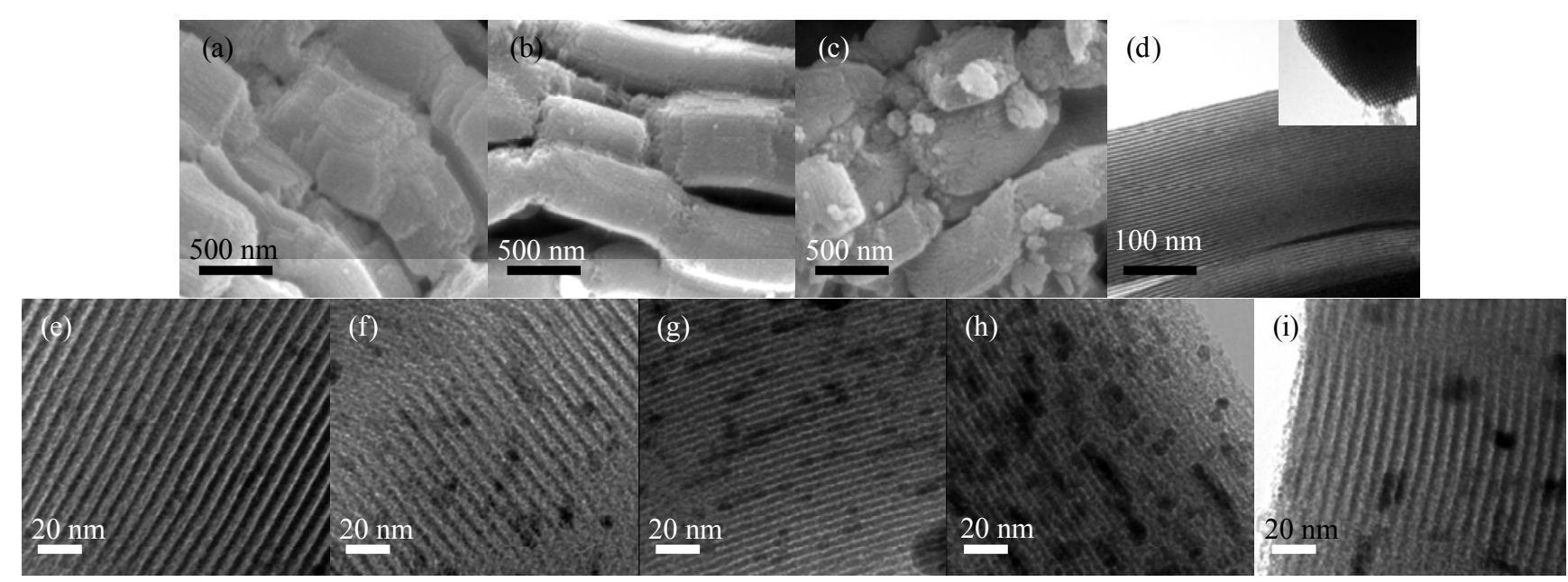

Fig. 6. SEM (a-c) and HRTEM(d-i) images of SBA-15 and Ag/SBA-15. (a, d) SBA-15; (e) 4.2\%Ag/SBA-15; (b, f) 5.3\%Ag/SBA-15; (g) 8.1\%Ag/SBA-15; (h) $16.5 \% \mathrm{Ag} / \mathrm{SBA}-15$; (c, i) $5.3 \% \mathrm{Ag} / \mathrm{SBA}-15-\mathrm{A}$.

degree directly affect the catalytic activity and reaction conditions. In $5.3 \% \mathrm{Ag} / \mathrm{SBA}-15$, the active Ag species size is about 6 $\mathrm{nm}$ and uniformly dispersed on the carrier surface. This increases the specific surface area of the active components, which enables low-temperature selective catalytic oxidation of benzyl alcohol; a conversion of $95 \%$ and selectivity of $86 \%$ were obtained at $220{ }^{\circ} \mathrm{C}$. The catalytic activity of $5.3 \% \mathrm{Ag} /$ SBA-15 is significantly higher than those of the other catalysts; the ordered channel structure and appropriate pore size of SBA-15 promote uniform dispersion of Ag on the support surface, resulting in a nano-confinement effect. Even when the reaction temperature reached $340{ }^{\circ} \mathrm{C}$, the active component remained highly dispersed and active, and the conversion of benzyl alcohol and selectivity for benzaldehyde were more than $97 \%$ and $90 \%$, respectively. If the Ag content is not less than $16.5 \%$, Ag aggregation in the SBA-15 channels results in formation of Ag nanorods and partial occupation of the channels. This hinders mass transfer of the reactants and products, and they remain in the channels for a long time. Thus, some of the generated benzaldehyde continues to be oxidized, so the selectivity is lower than $92 \%$. For $4.2 \% \mathrm{Ag} / \mathrm{SBA}-15$, although the Ag particle size is smaller its loading is lower, so there are fewer active sites; a proportion of the reactants passing through the fixed bed does not react, leading to lower catalytic activity.

In catalytic reactions, $\mathrm{O}_{2}$ is present as $\mathrm{O}^{2-}, \mathrm{O}^{-}$, and $\mathrm{O}_{2}{ }^{-}$. $\mathrm{Nu}-$ cleophilic oxygen $\left(\mathrm{O}^{2-}\right)$ is mainly responsible for the partial oxidation of organic compounds (hydrocarbons), and electrophilic oxygen $\left(\mathrm{O}^{-}\right.$and $\left.\mathrm{O}_{2}^{-}\right)$participates in the peroxidation reaction, leading to the formation of $\mathrm{CO}_{x}$ [52]. Benzaldehyde production depends on nucleophilic oxygen $\left(\mathrm{O}^{2-}\right)$ [53]. The characterization of $\mathrm{Ag} / \mathrm{SBA}-15$ shows that the active species were mainly $\mathrm{Ag}$ and a small amount of $\mathrm{Ag}_{2} \mathrm{O}$. Moreover, the active Ag species were almost uniformly dispersed on the support surface as a result of the nano-confinement effect of the porous SBA-15. The highly dispersed Ag nanoparticles helped to increase the specific surface area of the active components and therefore accelerated the formation of active oxygen species and promoted the migration of oxygen species to the sup- port surface, i.e., oxygen spillover [54]; the combination rate of reactive oxygen species with benzyl alcohol was increased as a result of the larger specific surface area, ordered channel structure, and appropriate pore size of the SBA-15. These factors improved the catalytic activity of Ag/SBA-15. Literature reports $[9,10,13]$ suggest that in the gas-phase selective oxidation of benzyl alcohol to benzaldehyde with gas-phase oxygen $\left(\mathrm{O}_{2}\right)$ as the oxidant and $\mathrm{Ag} / \mathrm{SBA}-15$ as the catalyst, gaseous $\mathrm{O}_{2}$ is first adsorbed on the surface of the Ag particles and receives electrons, and is then dissociated to form nucleophilic oxygen species. These species migrate to the SBA-15 surface by oxygen spillover, and benzyl alcohol molecules adsorbed on the support surface are oxidized by the nucleophilic oxygen species. Active nucleophilic oxygen species can activate the $\mathrm{C}-\mathrm{H}$ and $\mathrm{O}-\mathrm{H}$ bonds in benzyl alcohol, and the subsequent reactions produce benzaldehyde.

\subsection{Deactivation and regeneration of 5.3\% Ag/SBA-15 catalyst}

Figure 7 shows the deactivation and regeneration of $5.3 \% \mathrm{Ag} / \mathrm{SBA}-15$ in the gas-phase selective oxidation of benzyl alcohol. It can be seen that the conversion of benzyl alcohol and the selectivity for benzaldehyde initially reached $97 \%$ and $80 \%$, respectively. After reaction for $5 \mathrm{~h}$, the conversion dropped to $94 \%$, the selectivity rose to $97 \%$, and then stabilized. After $11 \mathrm{~h}$, the catalytic activity declined sharply to $60 \%$; there were no obvious changes in the selectivity. At this time, the raw material feed was stopped, and the temperature of the catalyst bed was increased to $500{ }^{\circ} \mathrm{C}$ and maintained for $2 \mathrm{~h}$ to activate the catalyst. Benzyl alcohol was then fed into the reactor, and the conversion of benzyl alcohol and the selectivity for benzaldehyde increased to $92 \%$ and $95 \%$, respectively. Catalyst deactivation may result from carbon deposition on the catalyst surface during the reaction [11]. The activity of the spent catalyst could therefore be recovered by simple oxidation. After two reaction-regeneration cycles, the catalytic activity and selectivity were both above $90 \%$, and the changes were slight. However, after three activation cycles, the catalytic activity and selectivity of the regenerated catalyst were significantly lower 


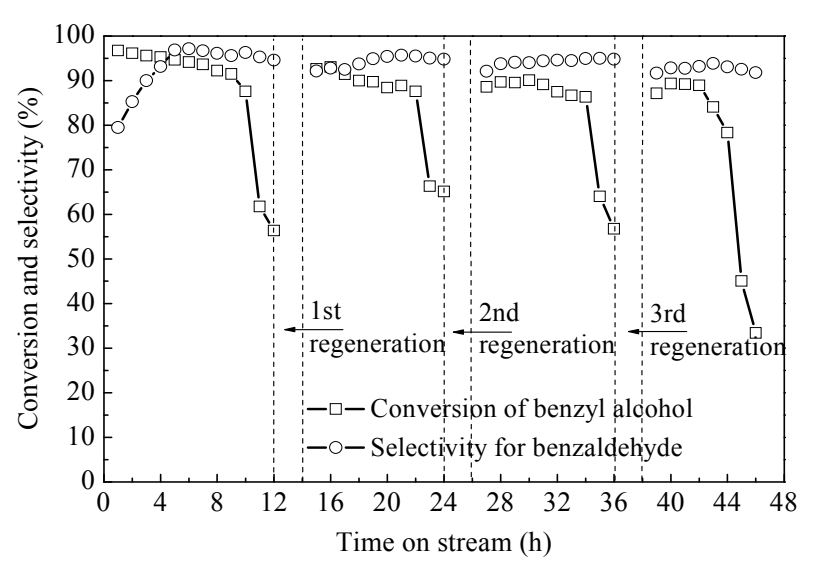

Fig. 7. Reaction/regeneration cycle tests of $5.3 \% \mathrm{Ag} / \mathrm{SBA}-15$ catalyst in gas-phase selective oxidation of benzyl alcohol to benzaldehyde. Reaction conditions: catalyst $0.8 \mathrm{~g}, 240{ }^{\circ} \mathrm{C}$, WHSV $=7.8 \mathrm{~h}^{-1}, n\left(\mathrm{O}_{2}\right) / n$ (benzyl alcohol $)=0.6$. Regeneration in $\mathrm{N}_{2}+\mathrm{O}_{2}\left(\mathrm{O}_{2}: \mathrm{N}_{2}\right.$ volume ratio of $3: 7$ and flow rate $50 \mathrm{~mL} / \mathrm{min}$ ) at $500{ }^{\circ} \mathrm{C}$ for $2 \mathrm{~h}$.

than those of fresh one. The conversion was less than $90 \%$ and began to decline after only $4 \mathrm{~h}$; after $6 \mathrm{~h}$ the conversion was lower than $80 \%$. Deactivation of the catalyst may be caused by the reduction of the active components or irreversible inactivation during long-term use and repeated treatment at high temperature. After three activation cycles, the catalyst $5.3 \% \mathrm{Ag} /$ SBA-15-A, which had been used in the reaction for $40 \mathrm{~h}$, was washed, calcined, and then characterized using $\mathrm{N}_{2}$ adsorptiondesorption, XRD, SEM, and TEM. The results showed that 5.3\%Ag/SBA-15-A still showed typical type IV isotherms (Fig. 4(a)) with H1-type hysteresis; the pore size distribution was broader (Fig. 4(b)), and the specific surface area and pore volume were smaller (Table 2) than the fresh one. The XRD pattern (Fig. 5(b)) of 5.3\%Ag/SBA-15-A shows that the intensity of the Ag diffraction peak increased, showing aggregation of some of the Ag after reaction for $40 \mathrm{~h}$ (Fig. 5(b)). There were clear stripes on the surface of $5.3 \% \mathrm{Ag} / \mathrm{SBA}-15-\mathrm{A}$, and the SEM image showed no obvious changes in the surface morphology (Fig. 6(c)), indicating that the catalyst had good mechanical stability. The appearance of the catalyst samples after reaction was not as neat as that of fresh one, and some fragmentation was observed; this may be the result of damage during tableting, crushing, and other operations in the catalyst-molding process. The 5.3\%Ag/SBA-15-A catalyst had an ordered hexagonal mesoporous structure (Fig. 6(i)), its Ag content was significantly reduced, and Ag aggregation clearly occurred in the channels, so the channels were clogged. These results are in agreement with the $\mathrm{N}_{2}$ adsorption-desorption and XRD results. Based on these results, it can be concluded that Ag/SBA-15 had a neat and ordered pore structure and thick pore walls, which significantly improved the activity and selectivity for benzaldehyde.

\section{Conclusions}

SBA-15 mesoporous materials have highly ordered hexagonally arranged cylindrical pore structure, thick pore walls, and high specific surface area. As a result of the nano-confinement effect of the SBA-15 ordered channels, Ag was successfully incorporated into the mesoporous channels and dispersed uniformly on the SBA-15 surface. This is beneficial for generation of nucleophilic oxygen species via oxygen spillover from $\mathrm{Ag}$ to the SBA-15 surface and improves the catalytic activity in the low-temperature selective gas-phase oxidation of benzyl alcohol to benzaldehyde. When the reaction temperature was 220 ${ }^{\circ} \mathrm{C}$, the conversion of benzyl alcohol and the selectivity for benzaldehyde reached $87 \%$ and $95 \%$, respectively. The best catalytic properties were obtained at $240{ }^{\circ} \mathrm{C}$, with benzyl alcohol conversion of $94 \%$ and benzaldehyde selectivity of $97 \%$. The benzyl alcohol conversion and benzaldehyde selectivity were almost unchanged with increasing temperature from 240 to $300{ }^{\circ} \mathrm{C}$, showing that the catalyst had excellent thermal gradient stability.

\section{References}

[1] Sheldon R A, Kochi J K. Metal-Catalyzed Oxidation of Organic Compounds. New York: Academic Press, 1981. 350

[2] Han G D. Handbook of Organic Chemistry Preparation. Beijing: Chemical Industry Press (韩广甸. 有机制备化学手册. 北京: 化学 工业出版社), 1975. 131

[3] Brückner A. Appl Catal A, 2000, 200: 287

[4] Jia L H, Zhang S, Song H, Guo X F, Zhao T. CIESC J (贾丽华, 张森, 宋 贺，郭祥峰，赵婷. 化工学报), 2009, 60: 2210

[5] Liu C, Tan R, Yin D H, Yu N Y, Zhou Y X. Chin J Catal (刘成, 谭蓉, 银 董红, 喻宁亚, 周裕旭. 催化学报), 2010, 31: 1369

[6] Zhan G W, Hong Y L, Mbah V T, Huang J L, Ibrahim A R, Du M M, Li Q B. Appl Catal A, 2012, 439-440: 179

[7] Pina C D, Falletta E, Rossi M. J Catal, 2008, 260: 384

[8] Zhao G F, Huang J, Jiang Z, Zhang S, Chen L, Lu Y. Appl Catal B, 2013, 140-141: 249

[9] Yamamoto R, Sawayama Y, Shibahara H, Ichihashi Y, Nishiyama S, Tsuruya S. J Catal, 2005, 234: 308

[10] Deng M M, Zhao G F, Xue Q S, Chen L, Lu Y. Appl Catal B, 2010, 99: 222

[11] Mao J P, Deng M M, Chen L, Liu Y, Lu Y. AIChE J, 2010, 56: 1545

[12] Mao J P, Deng M M, Xue Q S, Chen L, Lu Y. Catal Commun, 2009, 10: 1376

[13] Jia L H, Zhang S, Gu F N, Ping Y, Guo X F, Zhong Z Y, Su F B. Microporous Mesoporous Mater, 2012, 149: 158

[14] Zhao G F, Hu H Y, Deng M M, Lu Y. Chem Commun, 2011, 47: 9642

[15] Fan J, Dai Y H, Li Y L, Zheng N F, Guo J F, Yan X Q, Stucky G D. J Am Chem Soc, 2009, 131: 15568

[16] Zhao G F, Deng M M, Jiang Y F, Hu H Y, Huang J, Lu Y. J Catal, 2013, 301: 46

[17] Li C L, Zhang Q H, Wang Y, Wan H L. Chin J Catal (李常丽, 张庆红, 王野, 万惠霖. 催化学报), 2008, 29: 37

[18] Turner E A, Huang Y N, Corrigan J F. Eur J Inorg Chem, 2005, 2005: 4465

[19] Han Y J, Kim J M, Stucky G D. Chem Mater, 2000, 12: 2068

[20] Van der Meer J, Bardez-Giboire I, Mercier C, Revel B, Davidson A, Denoyel R. J Phys Chem C, 2010, 114: 3507

[21] Zienkiewicz-Strzałka M, Pasieczna-Patkowska S, Kozak M, Pikus S. Appl Surf Sci, 2013, 266: 337

[22] Lu H Q, Shi L, He C, Weng W Z, Huang C J, Wan H L. Acta Phys-Chim Sin (鲁怀乾, 石否, 何冲, 翁维正, 黄传敬, 万惠霖. 物理化学学 报), 2012, 28: 2697

[23] Zhang M L, Ji S F, Hu L H, Yin F X, Li C Y, Liu H. Chin J Catal (张美丽, 季生福, 胡林华, 银凤(翔, 李成岳, 刘辉. 催化学报), 2006, 27: 777 


\title{
Graphical Abstract
}

Chin. J. Catal., 2014, 35: 108-119 doi: 10.1016/S1872-2067(12)60720-7

Catalytic activity of Ag/SBA-15 for low-temperature gas-phase selective oxidation of benzyl alcohol to benzaldehyde

Liang Ma, lihua Jia*, Xiangfeng Guo*, Lijun Xiang

Qiqihar University

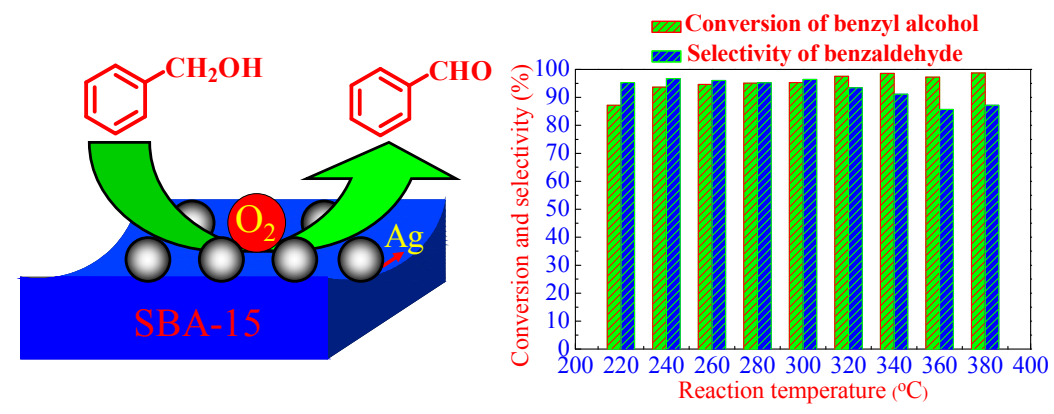

$\mathrm{Ag} / \mathrm{SBA}-15$ catalyst for the gas-phase selective oxidation of benzyl alcohol to benzaldehyde with $\mathrm{O}_{2}$ was prepared using an impregnation method. Ag/SBA-15 displayed good catalytic activity at low temperature and excellent thermal gradient stability.

[24] Chiang C W, Wang A Q, Wan B Z, Mou C Y.J Phys Chem B, 2005, 109: 18042

[25] Vinoba M, Bhagiyalakshmi M, Jeong S K, Yoon Y II, Nam S C. J Phys Chem C, 2011, 115: 20209

[26] Zhao F Z, Zeng P H, Zhang G H, Ji S F, Li C Y. Chin J Catal (赵福真, 曾鹏晖, 张广宏, 季生福, 李成岳. 催化学报), 2010, 31: 335

[27] Liu X Y, Wang A Q, Wang X D, Mou C Y, Zhang T. Chem Commun, 2008: 3187

[28] Yang C M, Kalwei M, Schüth F, Chao K J. Appl Catal A, 2003, 254: 289

[29] Dai W, Zhou Y P, Li S N, Li W, Su W, Sun Y, Zhou L. Ind Eng Chem Res, 2006, 45: 7892

[30] Chen X, Zhao W G, Wang F, Xu J.J Nat Gas Chem, 2012, 21: 481

[31] Tang L, Shao Y, Wan H Q, Xu Z Y, Zheng S R. Chin J Inorg Chem (唐 亮, 邵芸, 万海勤, 许昭怡, 郑寿荣. 无机化学学报), 2011，27: 1691

[32] Huang X B, Dong W J, Wang G, Yang M, Tan L, Feng Y H, Zhang X X. J Colloid Interface Sci, 2011, 359: 40

[33] Huang X B, Yang M, Wang G, Zhang X X. Microporous Mesoporous Mater, 2011, 144: 171

[34] Zhu W P, Han Y C, An L J. Microporous Mesoporous Mater, 2005, 80 : 221

[35] Jiang L, Liu W, Yao J L, Chen B, Gu R A. Acta Chim Sin (蒋丽, 刘伟, 姚建林, 陈彪, 顾仁敖. 化学学报), 2011, 69: 2368

[36] Han J, Fang P, Jiang W J, Li L Y, Guo R. Langmuir, 2012, 28: 4768

[37] Zhu J, Konya Z, Puntes V F, Kiricsi I, Miao C X, Ager J W, Alivisatos A P, Somorjai G A. Langmuir, 2003, 19: 4396

[38] Qu Z P, Shen S J, Chen D, Wang Y. J Mol Catal A, 2012, 356: 171
[39] Anand N, Reddy K H P, Prasad G V S, Rao K S R, Burri D R. Catal Commun, 2012, 23: 5

[40] Tu C H, Wang A Q, Zheng M Y, Meng Y, Shan J H, Zhang T. Chin J Catal (涂彩华, 王爱琴, 郑明远, 孟云, 单继宏, 张涛. 催化学报), 2005, 26: 631

[41] Tian D, Yong G P, Dai Y, Yan X Y, Liu S M. Catal Lett, 2009, 130: 211

[42] Zhao F Z, Zeng P H, Ji S F. Chin J Inorg Chem (赵福真, 曾鹏辉, 季生 福. 无机化学学报), 2013, 29: 753

[43] Zhao D Y, Feng J L, Huo Q S, Melosh N, Fredrickson G H, Chmelka B F, Stucky G D. Science, 1998, 279: 548

[44] Zhao D Y, Sun J Y, Li Q Z, Stucky G D. Chem Mater, 2000, 12: 275

[45] Chen D, Qu Z P, Zhang W W, Li X Y, Zhao Q D, Shi Y. Colloids Surf A, 2011, 379: 136

[46] Tian D, Yong G P, Liu S M. Chem J Chin Univ (田冬, 雍国平, 刘少民. 高等学校化学学报), 2009, 30: 2367

[47] Lopez-Salido I, Lim D C, Kim Y D. Surf Sci, 2005, 588: 6

[48] Lai Y K, Zhuang H F, Xie K P, Gong D G, Tang Y X, Sun L, Lin C J, Chen Z. New J Chem, 2010, 34: 1335

[49] Wang Z J, Xie Y B, Liu C J.J Phys Chem C, 2008, 112: 19818

[50] Yang C M, Liu P H, Ho Y F, Chiu C Y, Chao K J. Chem Mater, 2003, 15: 275

[51] Imperor-Clerc M, Davidson P, Davidson A. J Am Chem Soc, 2000, 122: 11925

[52] Sokolovskii V D. Catal Rev-Sci Eng, 1990, 32: 1

[53] Bulushev D A, Reshetnikov S I, Kiwi-Minsker L. Appl Catal A, 2001, 220: 31

[54] Pajonk G M. Appl Catal A, 2000, 202: 157

\section{Ag/SBA-15低温气相选择性催化氧化苯甲醇合成苯甲醛}

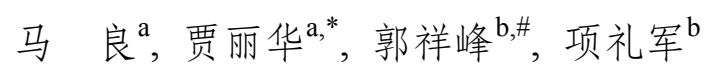 \\ a 齐齐哈尔大学黑龙江省普通高校精细化工重点实验室, 黑龙江齐齐哈尔 161006 \\ ${ }^{\mathrm{b}}$ 齐齐哈尔大学化学与化学工程学院, 黑龙江齐齐哈尔 161006
}

摘要: 以SBA-15为载体, 采用浸渍法制备了不同 $\mathrm{Ag}$ 含量的 $\mathrm{Ag} / \mathrm{SBA}-15$, 通过 $\mathrm{N}_{2}$ 吸附-脱附、X射线衍射、扫描电子显微镜、高分辨 透射电子显微镜、X射线光电子能谱和电感耦合等离子体质谱对催化剂进行了表征. 将Ag/SBA-15用于苯甲醇气相选择性催化氧 
化合成苯甲醛, 研究了反应条件对转化率和选择性的影响. 结果表明, Ag/SBA-15具有均一的一维孔道结构、较厚的孔壁(3-5 nm) 及较大的比表面积(411-541 m²/g), 其规整纳米空间的限域作用使一定负载量的Ag以纳米尺寸均匀分散于介孔SBA-15孔道内, 增 加了活性组分的比表面积. 亲核性氧物种从 $\mathrm{Ag}$ 到 SBA-15表面的氧溢流, 提高了低温下 $\mathrm{Ag} / \mathrm{SBA}-15$ 对苯甲醇气相选择性氧化合成 苯甲醛的催化性能. $5.3 \% \mathrm{Ag} / \mathrm{SBA}-15$ 中的 $\mathrm{Ag}$ 粒径为 5-6 nm, 且均匀分散于载体孔道中, 反应温度为 $220^{\circ} \mathrm{C}$ 时, 苯甲醇转化率为 $87 \%$, 苯甲醛选择性为 $95 \% ; 240{ }^{\circ} \mathrm{C}$ 时, 苯甲醇转化率和苯甲醛选择性分别高达 $94 \%$ 和 $97 \%$; 并在 $240-300{ }^{\circ} \mathrm{C}$ 范围内, 其催化活性和 选择性保持不变, 表现出了良好的温度耐受能力. 催化剂经活化再生可以连续使用 $40 \mathrm{~h}$, 选择性基本保持不变.

关键词: 银; SBA-15; 低温气相氧化; 苯甲醇; 苯甲醛

收稿日期: 2013-08-11. 接受日期: 2013-09-22. 出版日期: 2014-01-20.

*通讯联系人. 电话: (0452)2742573; 电子信箱: j1h29@163.com

通讯联系人. 电话: (0452)2742563; 电子信箱: xfguo@163.com

基金来源：国家自然科学基金(21176125); 黑龙江省教育厅科研项目(12521594, 2012TD012, JX201205); 齐齐哈尔市科技局项目 (GYGG-201108).

本文的英文电子版由Elsevier出版社在ScienceDirect上出版(http://www.sciencedirect.com/science/journal/18722067).

\section{1. 前言}

苯甲醛是一种重要的有机合成中间体 ${ }^{[1]}$, 广泛应用 于化妆品、香料、食品和医药工业 ${ }^{[2]}$. 目前工业和实验 室中多采用甲苯气相氧化 ${ }^{[3]}$ 或苯甲醇液相氧化 ${ }^{[4-6]}$ 制备 苯甲醛, 但往往副产物多, 选择性低, 产物难分离, 因而 限制了苯甲醛的应用. 近年来, 以分子氧为氧化剂, 利用 固定床反应器, 气固相选择性催化氧化苯甲醇制备苯甲 醛, 由于无溶剂, 副产物少, 产物易分离及反应工艺绿色 环保而备受人们的关注. 反应多采用负载型金属催化 剂, 如 $\mathrm{Au}-\mathrm{Cu} / \mathrm{SiO}_{2}{ }^{[7]}, \mathrm{Au} / \mathrm{Ni}$ - 纤 维 ${ }^{[8]}, \mathrm{Ag} / \mathrm{SiO}_{2}{ }^{[9]}, \mathrm{Ag}$ 纤 维 ${ }^{[10,11]}, \mathrm{Ag} / \mathrm{Ni}$-纤维 ${ }^{[12]}$ 和 $\mathrm{Ag}-\mathrm{HMS}^{[13]}$ 等, 反应温度均在 $300{ }^{\circ} \mathrm{C}$ 以上. Zhao等 ${ }^{[14]}$ 采用电沉积法将 $\mathrm{Au}$ 颗粒负载在 $\mathrm{Ni}$-纤维载体上, 制得了 $\mathrm{Au} / \mathrm{Ni}$-纤维型催化剂, $\mathrm{Au}$ 负载量 为 $4 \%, 280{ }^{\circ} \mathrm{C} 反$ 应时, 苯甲醇的转化率达到了 $99 \%$, 苯甲 醛选择性高达 $98 \%$. Fan等 ${ }^{[15]}$ 使用 $\mathrm{K}-\mathrm{Cu}-\mathrm{TiO}_{2}$ 催化剂, 在 接近苯甲醇沸点 $203-223{ }^{\circ} \mathrm{C}$ 条件下, 获得苯甲醇转化率 $72 \%$, 苯甲醛选择性大于 $98 \%$; 该催化剂对反应温度的 控制要求比较严格, 温度高于 $250{ }^{\circ} \mathrm{C}$ 时, 目的产物苯甲 醛过氧化几乎完全生成苯甲酸. 低温气相选择性催化氧 化苯甲醇生成苯甲醛, 反应温度低, 不仅有利于提高目 的产物选择性, 提高活性位的寿命, 而且节能环保, 引起 人们越来越多的重视 ${ }^{[16]}$.

纯硅SBA-15介孔分子篮具有长程有序的一维孔道 结构, 介孔尺寸可在4.6-30 nm范围内调控, 孔壁较厚, 比 表面积高, 水热稳定性好, 且表面存在大量的硅羟基, 易 于改性. 同时, 利用其规整纳米空间的限域作用制备纳 米活性相是制备功能性纳米材料的有效方法之一 ${ }^{[17-22]}$, 因此被广泛应用于催化和吸附工业 ${ }^{[23-31]}$. 其中Ag改性 的SBA-1 $5^{[32-37]}$ 由于在甲醛氧化 ${ }^{[38]}$ 、环烷烃的选择性氧 化 ${ }^{[39]}$ 和 $\mathrm{CO}$ 氧化 ${ }^{[40-42]}$ 等反应中表现出较好的催化性能,
引起了研究者的广泛兴趣. 然而, 将Ag/SBA-15用于苯 甲醇气相选择性催化氧化制备苯甲醛鲜有报道.

本文以介孔SBA-15为载体, 采用浸渍法合成了一系 列不同 $\mathrm{Ag}$ 负载量的 $\mathrm{Ag} / \mathrm{SBA}-15$, 利用 $\mathrm{N}_{2}$ 吸附-脱附、 $\mathrm{X}$ 射 线衍射 $(X R D)$ 、扫描电镜 $(\mathrm{SEM})$ 、高分辨透射电镜 (HR-TEM)、X射线光电子能谱(XPS)和电感耦合等离子 体质谱(ICP-MS)等手段对催化剂结构及活性组分进行 了表征. 并以分子氧为氧源, 在不添加任何助剂的条件 下, 将其用于苯甲醇气相选择性催化氧化反应, 考察了 $\mathrm{Ag}$ 的负载量对催化剂结构的影响, 以及催化剂结构与性 能之间的关系, 研究了反应温度对苯甲醇转化率和苯甲 醛选择性的影响, 在此基础上考察了催化剂的使用寿命.

\section{2. 实验部分}

\subsection{Ag/SBA-15催化剂制备}

载体SBA-15参照文献 $[43,44]$ 方法制备. $40{ }^{\circ} \mathrm{C}$ 下, 将 $4.2 \mathrm{~g} \mathrm{P} 123\left(\mathrm{EO}_{20} \mathrm{PO}_{70} \mathrm{EO}_{20}, M_{\mathrm{w}}=5800\right.$, 美 国 Sigma-Aldrich公司)加入到 $60 \mathrm{~g} \mathrm{HCl}(4.0 \mathrm{~mol} / \mathrm{L})$ 与 $90 \mathrm{~g}$ 去离子水混 合溶液中, 磁力搅拌 $2 \mathrm{~h}$ 得溶液 $\mathrm{A}$. 将 $8.5 \mathrm{~g}$ 正硅酸乙酯 (TEOS, AR, 98\%)缓慢滴加到溶液 A中. $40{ }^{\circ} \mathrm{C}$ 下搅拌 24 $\mathrm{h}$ 后, 将所得混合液转移到带有聚四氟乙烯内祄的不锈 钢水热反应釜中, $100{ }^{\circ} \mathrm{C}$ 恒温晶化 $24 \mathrm{~h}$. 经过滤得到白 色固体, 用去离子水洗涤三次, $60^{\circ} \mathrm{C}$ 干燥过夜. 研磨后 于 $550{ }^{\circ} \mathrm{C}$ 焙烧 $6 \mathrm{~h}$, 即得到白色粉末状固体SBA-15.

取 $1.0 \mathrm{~g}$ 新制 $\mathrm{SBA}-15$ 载体浸渍在 $50 \mathrm{~mL}$ 不同浓度的 $\mathrm{AgNO}_{3}$ 溶液中, $50{ }^{\circ} \mathrm{C}$ 下磁力搅拌 $10 \mathrm{~h}$, 然后于 $100{ }^{\circ} \mathrm{C}$ 干 燥过夜, $500{ }^{\circ} \mathrm{C}$ 焙烧 $6 \mathrm{~h}$, 即得不同 $\mathrm{Ag}$ 含量的 $\mathrm{Ag} / \mathrm{SBA}-15$ 催化剂 ${ }^{[39,45]}$, 记为 $x \mathrm{Ag} / \mathrm{SBA}-15$, 其中 $x$ 代表利用 ICP-MS 测定的 $\mathrm{Ag}$ 的质量分数). 将反应 $40 \mathrm{~h}$ 后的 $5.3 \% \mathrm{Ag} /$ SBA-15用乙醇洗涤, 过滤, 于 $80{ }^{\circ} \mathrm{C}$ 干燥过夜, $500{ }^{\circ} \mathrm{C}$ 焙 烧 $2 \mathrm{~h}$, 所得再生催化剂记为 $5.3 \% \mathrm{Ag} / \mathrm{SBA}-15-\mathrm{A}$. 


\section{2. 催化剂表征}

XRD在德国Bruker D8 Advance型粉末衍射仪上测 定, $\mathrm{Cu}$ 靶 $K_{a}$ 射线, $\mathrm{Ni}$ 滤波器, 管电压 $60 \mathrm{kV}$, 管电流 300 $\mathrm{mA}$, 功率 $18 \mathrm{~kW}$, 扫描速度 $3 \% \mathrm{~min}$, 扫描范围 $2 \theta=$ $0.5^{\circ}-80^{\circ}$. $\mathrm{N}_{2}$ 吸附-脱附等温线在Quantachrome NOVA $2000 \mathrm{e}$ 型物理吸附仪上测量, 吸附质为 $\mathrm{N}_{2}$, 吸附温度为 $-196{ }^{\circ} \mathrm{C}$, 测试前样品在 $300{ }^{\circ} \mathrm{C}$ 真空条件下预处理 $3 \mathrm{~h}$, 样 品的比表面积、孔径和孔体积分别用BET和BJH法计算 得到. SEM在日本日立公司S-4300型场发射扫描电子显 微镜上拍摄, 电压 $20 \mathrm{kV}$, 样品室真空度优于 $1 \times 10^{-4}$. HR-TEM在美国FEI公司Tecnai G2型透射电子显微镜上 拍摄，电压 $200 \mathrm{kV}$. 采用英国 Thermo Electron公司 ESCALAB 250Xi型X射线光电子能谱(XPS)仪分析样品 中 $\mathrm{Ag}$ 的结合态, 激发源为 $\mathrm{Al} K_{\alpha}$ 射线 $(1486 \mathrm{eV})$. 利用 Agilent $7500 \mathrm{ce}$ 型电感耦合等离子体质谱仪测定催化剂 中 $\mathrm{Ag}$ 的含量, 测试前将催化剂用 $\mathrm{HCl}(3 \mathrm{~mL}), \mathrm{HF}(1 \mathrm{~mL})$ 和 $\mathrm{HNO}_{3}(1 \mathrm{~mL})$ 溶解, 使用 $3 \% \mathrm{HNO}_{3}$ 溶液定容到 $100 \mathrm{~mL}$.

\section{3. 催化剂评价}

采用常压连续固定床反应器(内径 $6 \mathrm{~mm}$, 长 $450 \mathrm{~mm}$ ) 进行苯甲醇气相选择性催化氧化反应. 将 $0.8 \mathrm{~g}$ 催化剂 (40-60目)装入反应器中, 两端用石英砂和石英棉封堵. 在 $\mathrm{N}_{2}$ 和 $\mathrm{O}_{2}$ 体积比为 $3: 7$, 总流速为 $50 \mathrm{~mL} / \mathrm{min}$ 的条件下于 $500{ }^{\circ} \mathrm{C}$ 活化 $2 \mathrm{~h}$. 随后通入载气 $\mathrm{N}_{2}(35 \mathrm{~mL} / \mathrm{min})$ 、反应物 $\mathrm{O}_{2}$ 和苯甲醇, 重时空速(WHSV) 为 4.7-12.5 $\mathrm{h}^{-1}, \mathrm{O}_{2}$ / 苯甲 醇摩尔比为 0.6 . 使用微量进样控制器调节苯甲醇进料 速率, 在 $220^{\circ} \mathrm{C}$, 气化后通入反应器. 反应温度 $220-$ $380^{\circ} \mathrm{C}$, 反应产物经冰盐浴 $\left(-5\right.$ 到 $\left.-10^{\circ} \mathrm{C}\right)$ 冷却后收集. 用 GC-9800型气相色谱仪对产物进行定量分析. 使用 OV-17毛细管柱 $(30 \mathrm{~m} \times 0.25 \mathrm{~mm} \times 0.25 \mu \mathrm{m})$, FID检测器, 柱温 $140{ }^{\circ} \mathrm{C}$, 检测器温度 $200^{\circ} \mathrm{C}$, 进样器温度 $200{ }^{\circ} \mathrm{C}$, 载气 $\left(\mathrm{N}_{2}\right)$ 流速 $180 \mathrm{~mL} / \mathrm{min}$, 空气 $0.3 \mathrm{MPa}$, 氢气 $0.35 \mathrm{MPa}$, 柱前 压 $0.07 \mathrm{MPa}$, 进样量 $0.04 \mu \mathrm{L}$. 根据反应产物中各物质的 含量、总投料量及产物质量计算苯甲醇转化率、苯甲醛 选择性、苯甲醛收率及TOF.

\section{3. 结果与讨论}

\subsection{Ag/SBA-15的催化性能}

\subsubsection{Ag负载量的影响}

表 1 为不同 $\mathrm{Ag}$ 负载量的 $\mathrm{Ag} / \mathrm{SBA}-15$ 催化剂上苯甲醇 气相选择性催化氧化制苯甲醛反应性能. 反应温度为 $240{ }^{\circ} \mathrm{C}$ 时, SBA-15无催化活性, 负载 $\mathrm{Ag}$ 后催化活性显著 增加, 随着 $\mathrm{Ag}$ 负载量由 $4.1 \%$ 逐渐增至 $16.5 \%$, 苯甲醇转
化率由 $74.8 \%$ 逐步升到 $96.6 \%$, 而苯甲醛选择性由 $85.2 \%$ 先增加到 $96.9 \%$, 之后下降到 $91.5 \%$. 可能是由于 $\mathrm{Ag}$ 负载 量过多时, 苯甲醛过氧化生成苯甲酸, 导致其选择性降 低. 可见, 当 $\mathrm{Ag}$ 负载量为 $5.3 \%$ 时催化剂性能较佳: 苯甲 醇转化率 $94 \%$, 苯甲醛选择性 $97 \%$, TOF值 $128.6 \mathrm{~h}^{-1}$.

\subsection{2. 反应温度的影响}

温度是影响苯甲醇气相选择性催化氧化反应转化 率和选择性的重要因素 ${ }^{[12-16]}$. 图 1 为 $5.3 \% \mathrm{Ag} / \mathrm{SBA}-15$ 催 化剂上反应温度对苯甲醇气相选择性催化氧化反应的 影响. 由图可知, 反应温度 $220{ }^{\circ} \mathrm{C}$ 时, 苯甲醇转化率和苯 甲醛选择性分别为 $86 \%$ 和 $95 \%$. 可见, 在较低温度下, $\mathrm{Ag} / \mathrm{SBA}-15$ 可有效实现选择性催化氧化苯甲醇生成苯甲 醛. 升温至 $240{ }^{\circ} \mathrm{C}$, 苯甲醇转化率上升到 $94 \%$, 苯甲醛选 择性为 $97 \%$, 并在 $240-300{ }^{\circ} \mathrm{C}$ 范围内保持不变; 继续升 至 $340{ }^{\circ} \mathrm{C}$, 选择性降至 $90 \%$, 转化率略有上升; 至 $380{ }^{\circ} \mathrm{C}$ 时, 苯甲醛选择性为 $85 \%$, 苯甲醇转化率接近 $100 \%$, 液质 联用分析表明, 高温下部分苯甲醛氧化生成了苯甲酸, 从而使其选择性下降. 上述实验表明, Ag/SBA-15在较 低的温度下可选择性催化氧化苯甲醇生成苯甲醛, 并在 较宽的温度内保持高选择性, 具有很好的温度耐受性; 而且通过选择合适的催化剂和反应温度可调控反应活 性及苯甲醛选择性.

\subsection{3. 重时空速的影响}

图2为反应重时空速与催化性能的关系. 由图可知, 当WHSV $=4.7-12.5 \mathrm{~h}^{-1}, 5.3 \% \mathrm{Ag} / \mathrm{SBA}-15$ 上苯甲醛选择 性均在 $95 \%$ 以上, 同时TOF 由 $77.1 \mathrm{~h}^{-1}$ 上升到最大值 134.9 $\mathrm{h}^{-1}$ 后下降至 $127.6 \mathrm{~h}^{-1}$. WHSV $=7.8 \mathrm{~h}^{-1}$ 时, 苯甲醇转化率 和苯甲醛的选择性达到最大值, 分别为 $94 \%$ 和 $97 \%$, TOF 值为 $128.6 \mathrm{~h}^{-1}$; WHSV $=9.4 \mathrm{~h}^{-1}$, TOF值达最大, 为 134.9 $\mathrm{h}^{-1}$, 然而此时苯甲醇转化率仅为 $82.8 \%$. 综上所述, 最优 反应条件为: 反应温度 $240{ }^{\circ} \mathrm{C}$, WHSV 为 $7.8 \mathrm{~h}^{-1}$. 此时, 苯甲醇转化率为 $94 \%$, 苯甲醛选择性大于 $97 \%$.

\subsection{Ag/SBA-15催化活性与其结构的关系}

利用XPS表面探针技术研究了 $\mathrm{Ag} / \mathrm{SBA}-15$ 表面 $\mathrm{Ag}$ 的形态及其含量. 图 3 是 $5.3 \% \mathrm{Ag} / \mathrm{SBA}-15$ 中 $\mathrm{Ag} 3 d$ 的XPS 谱. 电子结合能为 374.4 和 $368.3 \mathrm{eV}$ 的谱峰分别对应 $\mathrm{Ag} 3 d_{3 / 2}$ 和 $\mathrm{Ag} 3 d_{5 / 2}$ 能带 ${ }^{[46,47]}$, 差值 $\Delta E=6.1 \mathrm{eV}$; 同时 $\mathrm{Ag}$ $3 d_{5 / 2}$ 的特征峰略有不对称, 分峰后得到 368.4 和 $367.8 \mathrm{eV}$ 处的两个特征谱峰, 分别对应于单质 $\mathrm{Ag}(90 \%)$ 和 $\mathrm{Ag}_{2} \mathrm{O}$ $(10 \%)^{[48]}$. 这说明在 $5.3 \% \mathrm{Ag} / \mathrm{SBA}-15$ 表面中 $\mathrm{Ag}$ 物种主要 以单质 $\mathrm{Ag}$ 和少量 $\mathrm{Ag}_{2} \mathrm{O}$ 形式存在 ${ }^{[13]}, \mathrm{Ag}$ 质量分数为 $0.33 \%$. 另外 ICP-MS 分析表明, $5.3 \% \mathrm{Ag} / \mathrm{SBA}-15$ 样品中 
$\mathrm{Ag}$ 含量为 $5.3 \%$, 可以估算出进入介孔孔道内的 $\mathrm{Ag}$ 含量 约为 $4.93 \%$, 也就是说 $93 \%$ 以上的 $\mathrm{Ag}$ 进入到 SBA- 15 的介 孔孔道. 结合评价结果表明, 单质 $\mathrm{Ag}$ 为苯甲醇气相选择 性催化氧化制苯甲醛反应的活性物种.

图4为各 $\mathrm{Ag} / \mathrm{SBA}-15$ 催化剂的 $\mathrm{N}_{2}$ 吸附-脱附等温线和 $\mathrm{BJH}$ 孔径分布曲线. 由图可见, 所有样品等温线均为 $\mathrm{IV}$ 型, 并在较高的相对压力 $\left(0.6<p / p_{0}<0.8\right)$ 下出现因 $\mathrm{N}_{2}$ 的 毛细凝聚而产生的 $\mathrm{H} 1$ 型滞后环. 其中吸附支与脱附支 在窄的相对压力范围内显示平行显著变化的趋势, 与 SBA-15分子笚具有规则、均一的开口圆筒形孔道 $(d>6$ $\mathrm{nm})$ 特征相一致 ${ }^{[43-45,49]}$. 同时, 随着 $\mathrm{Ag}$ 负载量增加, $\mathrm{Ag} / \mathrm{SBA}-15$ 样品显示有较宽相对压力范围的扁平滞后 环, 并且吸附与脱附分支闭合于略低的相对压力. 根据 开尔文定律, 孔径小时发生毛细凝聚的相对压力低, 表 明样品中出现墨水瓶形孔道 ${ }^{[13,50]}$. 该孔道的形成, 可能 是Ag进入孔道造成的; 由图4(b) 可知, 最可几孔径变小 且孔径分布宽化, 其中 $4.2 \% \mathrm{Ag} / \mathrm{SBA}-15$ 和 $5.3 \% \mathrm{Ag} /$ SBA-15样品还出现了孔径为 $3.7 \mathrm{~nm}$ 的小孔径, 它源于墨 水瓶形孔道的孔口过窄带来的假象, 进一步说明Ag进入 到SBA-15的孔道.

表 2 为 $\mathrm{Ag} / \mathrm{SBA}-15$ 催化剂的结构参数. 可以看出, 随 $\mathrm{Ag}$ 负载量从 0 增至 $16.5 \%$, 催化剂的比表面积、孔体积和 孔径分别从 $676 \mathrm{~m}^{2} / \mathrm{g}, 0.886 \mathrm{~cm}^{3} / \mathrm{g}$ 和 $6.57 \mathrm{~nm}$ 降低至 411 $\mathrm{m}^{2} / \mathrm{g}, 0.607 \mathrm{~cm}^{3} / \mathrm{g}$ 和 $6.19 \mathrm{~nm}$. 这可能是由于 $\mathrm{Ag}$ 粒子占据 了部分孔道空间, 使比表面积、孔体积和孔径减小. 同时 由脱附分支计算出孔径为 6-7 nm, 说明样品中并不存在 $3.7 \mathrm{~nm}$ 孔道. 由图 4 还可以看出, $\mathrm{Ag}$ 的负载对载体 SBA-15的规则孔道结构基本无影响, 且活性物种 Ag进 入了SBA-15孔道.

图 5(a)为 $\mathrm{Ag} / \mathrm{SBA}-15$ 的小角度XRD谱. 由图可知, 在 $2 \theta=1.4^{\circ}-2^{\circ}$ 范围内, 所有样品均出现两个衍射峰, 说明 样品仍保持了分子篮的典型六方介孔结构 ${ }^{[43]}$. 当 $\mathrm{Ag}$ 负 载量达到 $16.5 \%$ 时, 衍射峰强度明显减弱, 可能是由于 $\mathrm{Ag}$ 含量过高而使Ag在SBA-15 孔道内聚集, 导致SBA-15结 构发生变化. 图5(b)为各样品的广角XRD谱. 可以看出, 当 $\mathrm{Ag}$ 负载量为 $4.2 \%$ 和 $5.3 \%$ 时, $\mathrm{Ag}$ 的衍射峰不明显, 说明 $\mathrm{Ag}$ 高分散于载体表面. $2 \theta=38.4^{\circ}, 44.0^{\circ}, 64.3^{\circ}$ 和 $77.5^{\circ}$ 处 出现的特征衍射峰分别归属于 $\mathrm{Ag}$ 的(111), (200), (220)和 (311) 晶面(JCPDS No. 4-07830) ${ }^{[13,34,48]}$; 随着Ag负载量的 增加, $\mathrm{Ag}$ 特征衍射峰强度变大, 峰形更加尖锐, 说明 $\mathrm{Ag}$ 在SBA-15载体表面由高度分散状态转变为聚集状态, 与 XPS和 $\mathrm{N}_{2}$ 吸附-脱附结果相一致.
图6为SBA-15和 Ag/SBA-15的SEM和HR-TEM照片. 可以看出, SBA-15载体外观形貌呈短棒相接的长绳状, 表面呈现清晰波纹, 且带有细微的凹槽; Ag/SBA-15外 观形貌与纯SBA-15没有明显区别, 与文献[43,44]结果一 致, 说明采用浸渍法负载Ag不影响SBA-15的形貌. 由图 6(d) 可知, SBA-15孔道排列规则, 横截面呈有序六边形 排列(插图为 SBA-15垂直于 6 轴方向的TEM图), 为典型 的二维 $p 6 \mathrm{~mm}$ 六方相结构 ${ }^{[51]}$, 孔径约为 6-8 nm, 孔壁厚度 大约在 $3-5 \mathrm{~nm}$. 由图 6(e-h) 可知, 负载 $\mathrm{Ag}$ 后各样品仍具 有长程有序、孔径均一的孔道结构, 与文献一致 ${ }^{[49,50]}$. 当 $\mathrm{Ag}$ 含量为 $4.2 \%$ 和 $5.3 \%$ 时, $\mathrm{Ag}(\approx 6 \mathrm{~nm})$ 在 SBA-15载体表 面均匀分散; 至 $16.5 \%$ 时, 部分 $\mathrm{Ag}$ 在 SBA-15孔道中发生 聚集形成长度为 10-30 $\mathrm{nm}$ 的纳米棒, 占据部分孔道, 与 前文结果一致.

综上可见, $\mathrm{Ag} / \mathrm{SBA}-15$ 中 $\mathrm{Ag}$ 是活性相, 且 $\mathrm{Ag}$ 的负载 量、颗粒大小与分散程度直接影响其催化性能. $5.3 \% \mathrm{Ag} / \mathrm{SBA}-15$ 中的活性物种 $\mathrm{Ag}$ 以 $6 \mathrm{~nm}$ 颗粒均匀分散 在载体表面中, 增加了活性组分的比表面积, 显著提高 了 $5.3 \% \mathrm{Ag} / \mathrm{SBA}-15$ 的催化活性, 有利于实现低温选择性 催化氧化, $220{ }^{\circ} \mathrm{C}$ 时, 苯甲醇转化率和苯甲醛选择性分 别达 $86 \%$ 和 $95 \%$; SBA- 15 规则的孔道结构和适宜的孔径 对 $\mathrm{Ag}$ 的分散起到了很好的限域作用, 即使反应温度达到 $340{ }^{\circ} \mathrm{C}, \mathrm{Ag}$ 仍保持较好的高分散状态, 因而其催化活性 较高, 苯甲醇转化率大于 $97 \%$, 苯甲醛选择性达到 $90 \%$ 以 上. 对于 $\mathrm{Ag}$ 含量较高的 $16.5 \% \mathrm{Ag} / \mathrm{SBA}-15$, 由于 $\mathrm{Ag}$ 在 SBA-15孔道中部分发生聚集形成 $A g$ 纳米棒, 占据了部 分SBA-15孔道, 不利于传质, 反应物在孔道中停留时间 过长, 从而使部分生成的苯甲醛继续被氧化, 其选择性 低于 $92 \%$; 而对于 $4.2 \% \mathrm{Ag} / \mathrm{SBA}-15, \mathrm{Ag}$ 虽然粒径较小, 但 是负载量少, 以致活性位较少, 因而其催化活性仍不高, 苯甲醇转化率低于 $75 \%$.

$\mathrm{O}_{2}$ 在催化反应中的化学态有 $\mathrm{O}^{2-}, \mathrm{O}^{-}$和 $\mathrm{O}_{2}^{-}$, 亲核氧 $\left(\mathrm{O}^{2-}\right)$ 主要参与有机化合物 (碳氢化合物)的部分氧化反 应, 亲电氧 $\left(\mathrm{O}^{-}\right.$和 $\left.\mathrm{O}_{2}{ }^{-}\right)$参与深度氧化反应, 导致 $\mathrm{CO}_{x}$ 的形 成 ${ }^{[52]}$. 苯甲醛的生成取决于亲核氧 $\left(\mathrm{O}^{2-}\right)^{[53]}$. 由 $\mathrm{Ag} / \mathrm{SBA}-15$ 的表征结果可知, 活性物种 $\mathrm{Ag}$ 以单质 $\mathrm{Ag}$ 和少 量 $\mathrm{Ag}_{2} \mathrm{O}$ 存在. 由于载体SBA-15规则孔道结构对活性物 种 $\mathrm{Ag}$ 的限域作用, $\mathrm{Ag}$ 在载体表面均匀分散. 一方面, 高 度分散的纳米 $\mathrm{Ag}$ 使活性组分比表面积增大, 有益于活性 氧物种的生成, 也促进了活性氧物种迁移到载体表面, 形成氧溢流现象 ${ }^{[54]}$; 另一方面, 载体较大的比表面积、 规则的孔道结构和适宜的孔径大小加速了活性氧物种 
与反应物苯甲醇的结合速率, 使 $\mathrm{Ag} / \mathrm{SBA}-15$ 具有较好的 催化活性. 结合文献报道 ${ }^{[9,10,13]}$, 以气相氧 $\left(\mathrm{O}_{2}\right)$ 为氧化剂, $\mathrm{Ag} / \mathrm{SBA}-15$ 气相选择性催化氧化苯甲醇制备苯甲醛反应 中, 气相 $\mathrm{O}_{2}$ 首先吸附于富集电子的 $\mathrm{Ag}$ 颗粒表面并不断得 到电子, 发生解离形成亲核性氧物种, 后者溢流到 SBA-15载体表面, 与吸附于载体表面的苯甲醇分子发生 氧化反应. 活化的亲核性氧物种可以激活苯甲醇中的 C-H键和O-H键, 进而发生反应生成苯甲醛.

\section{3. $5.3 \% \mathrm{Ag} / \mathrm{SBA}-15$ 催化剂的失活与再生}

图 7 为 $5.3 \% \mathrm{Ag} / \mathrm{SBA}-15$ 在苯甲醇气相氧化反应中的 失活与再生情况. 由图可知, 在初始阶段, 苯甲醇的转化 率达到 $97 \%$, 产物选择性为 $80 \%$; 反应至第 $5 \mathrm{~h}$, 苯甲醇转 化率降至9 $4 \%$, 而苯甲醛选择性上升至 $97 \%$, 之后趋于平 稳; 至 $11 \mathrm{~h}$, 苯甲醇转化率急剧降至 $60 \%$, 而选择性无明 显变化. 此时停止通入原料, 床层温度升至 $500{ }^{\circ} \mathrm{C}$ 对催 化剂进行活化处理 $2 \mathrm{~h}$, 之后继续通入苯甲醇, 可以看到, 苯甲醇的转化率和苯甲醛的选择性分别恢复至 $92 \%$ 和 95\%. 这可能是由于催化剂在反应过程中发生积炭失 活 ${ }^{[11]}$, 因此简单的高温处理便可使催化剂再生. 同时可 以看到, 催化剂经过两个使用周期和两次活化后, 催化 活性和选择性变化不大, 均在 $90 \%$ 以上. 当进行三次活 化后, 再生催化剂活性和选择性明显低于新鲜催化剂, 且使用 $4 \mathrm{~h}$ 后, 催化剂活性便开始下降; 第6 h 时, 苯甲醇 转化率低于 $80 \%$, 可能是由于催化剂经长时间使用和多 次高温处理后, 活性组分减少或发生不可逆失活. 取出
经过三次活化且反应 $40 \mathrm{~h}$ 后的催化剂, 洗涤, 过滤, 焙烧 后(5.3\%Ag/SBA-15-A)对其表征发现该催化剂仍呈IV型 吸附-脱附等温线(图4(a)), H1 型滞后环, 孔径分布变宽 (图4(b)), 比表面积与孔体积(表2)较反应前有所下降. 另 外, 反应后催化剂的XRD谱(图5(b))中 $\mathrm{Ag}$ 衍射峰较反应 前的增强, 表明部分 $\mathrm{Ag}$ 发生了聚集. 从 SEM结果 (图 6(c)) 可以看出, 反应后的催化剂单节表面均呈清晰的条 纹状且主体形貌没有发生明显变化, 说明催化剂具有很 好的机械稳定性; 外部存在少量碎片, 外观形貌不如反 应前的规整, 这可能是催化剂成型过程中压片和粉碎等 操作造成的. 反应后的催化剂仍保持SBA-15的规则孔 道结构(图6(i)), $\mathrm{Ag}$ 明显减少并在孔道中发生聚集, 出现 堵塞孔道现象. 综上可以推断, Ag/SBA-15规整的形貌、 排列有序的孔道结构和较厚的孔壁显著提高了催化剂 活性和苯甲醛选择性.

\section{4. 结论}

$\mathrm{Ag} / \mathrm{SBA}-15$ 具有均一的一维孔道结构、较厚的孔壁 和较大的比表面积, 其规整纳米空间的限域作用使 $\mathrm{Ag}$ 以 纳米尺度高度分散在介孔SBA-15孔道内, 促进了亲核性 氧物种从 $\mathrm{Ag}$ 到 SBA-15的氧溢流, 有利于提高低温下苯 甲醇气相选择性氧化合成苯甲醛的选择性. 反应温度为 $220{ }^{\circ} \mathrm{C}$ 时, 苯甲醇转化率和苯甲醛选择性分别为 $87 \%$ 和 $95 \%, 240{ }^{\circ} \mathrm{C}$ 时, 分别为 $94 \%$ 和 $97 \%$, 并在 $240-300{ }^{\circ} \mathrm{C}$ 范围 内保持不变, 催化剂表现出了良好的温度耐受能力. 